\title{
Kaznodziejstwo epoki stanisławowskiej - inspiratorzy, twórcy, odbiorcy
}

Magdalena Ślusarska 


\title{
MAGDALENA ŚLUSARSKA
}

\author{
Kaznodziejstwo epoki stanisławowskiej \\ - inspiratorzy, twórcy, odbiorcy ${ }^{1}$
}

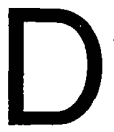

zieje Kościoła katolickiego w Polsce dowodzą, że pozostawał on zawsze tą instytucją życia publicznego, która wywierała wyraźny wpływ nie tylko w kwestiach wiary, religii czy kultury, ale także polityki i zależności społecznych. Wykorzystując różne formy oddziaływania na wiernych - duchowieństwo angażowało się w wewnętrzne problemy kraju. Epoka stanisławowska w Polsce, czyli lata 1764-1795, były w historii polskiego Kościoła katolickiego ostatnim okresem wszechstronnej działalności kleru, działalności, która wykraczała daleko poza ramy tradycyjnego ewangelicznego posłannictwa Kościoła. „Kościół oświecony" czy też „oświeceniowy katolicyzm” to funkcjonujące w historiografii terminy, które odzwierciedlają zasadniczą cechę Kościoła w latach panowania w Rzeczypospolitej jej ostatniego króla ${ }^{2}$. W polskiej XVIII-wiecznej rzeczywistości politycznej dotyczyło to wszechstronnych prób reform podjętych w łonie samego Kościoła (powrót do tradycji potrydenckich, czyli umocnienie wiary, likwidacja przerostów w obrzędowości, nowa ewangelizacja wśród wiernych, wśród wątpiących i niewierzących, wzmocnienie dyscypliny wewnętrznej, prawidłowa edukacja duchowieństwa, dostosowanie wykładu religijnego do wymogów współczesności) oraz wzbogacenia

\footnotetext{
1 Podstawowe założenia artykułu, dotyczące twórców i odbiorców kazań w epoce stanisławowskiej, prezentowane były na seminarium naukowym w Paryżu w sierpniu 1994 r.: Prédication de l'Église catholique en Pologne a l'époque de Stanislas Auguste: ses instigateurs, écrivains et auditeurs". (Est-West Seminar in Eighteenth-Century Studies zorganizowane przez Voltaire Foundation nt. Literature-public-public opinion).

2 Problemem „Oświecenia katolickiego" czy raczej „oświecenia chrześcijańskiego” interesowali się m.in.: S. Schwaiger, Oświecenie a katolicyzm, w: „Concilium”. R. 1966/67; s. 373-382; A. J. Zakrzewski, Idee Oświecenia w kazaniach polskich. (Studium literacko-socjologiczne). Częstochowa 1986 - praca ma wiele zasadniczych błędów merytorycznych i interpretacyjnych, wynikających z pobieżnego przeglądu materiału źródłowego oraz nieznajomości nurtów filozoficznych i politycznych realiów epoki; Y-C Gélébart, La Bible dans l'Aufklärung catholique, w: Le siècle des Lumiéres et la Bible sous la dir. de Y. Beleval, D. Bourel, Paris 1986, s. 563-577; B. Grochulska, Miejsce Kościoła w polskim Oświeceniu, w: „Mówią Wieki”, R. 1990, nr 11, s. 19-22. Artykuły poświęcone problemowi „oświecenia katolickiego” w specjalnym numerze „Znaku” R. 1992, nr 451 (12) - szczególnie wypowiedź J. Kracika, E. Bieńkowskiej i P. Lisickiego oraz praca najnowsza - S. Janeczek, Oświecenie chrześcijańskie. Z dziejów polskiej kultury filozoficznej, Lublin 1994.
} 
jego aktywności o wątki obywatelskie z zasady bliższe publicznej świeckiej dzia łalności politycznej, nie zaś duchownej3.

Od wieków Kościół oddziałuje na wiernych różnymi metodami. Najważniejsze to katechizacja, ambona i konfesjonał. $W$ ujęciu popularnym mówi się o wpływie poprzez „oko i ucho" drukowanym w tych epokach historycznych, w których umiejętność pisania i czytania dotyczyła wąskiego kręgu odbiorców. Tak też było w drugiej połowie XVIII wieku. Dla historyka rzetelne badanie zasięgu wpływu Kościoła na wiernych poprzez nauki głoszone z ambony napotyka trudności wynikające ze znikomości bezpośredniej bazy źródłowej, jaką byłyby spisane przekazy dotyczące reakcji słuchaczy na konkretne wystąpienia. Oczywiście możemy wyciągać wnioski na podstawie źródeł pośrednich, mając jednak świadomość niedokładności naszych stwierdzeń - ich hipotetycznego i teoretycznego charakteru. Aby tego uniknąć odwołuję się głównie do kaznodziejskiej działalności duchowieństwa, która po formie oralnej przybrała postać grafemiczną i następnie upowszechniona została dzięki drukowi. $Z$ dostępnych mi źródeł próbuję prześledzić drogę od inspiracji i powstania kazania po jego odbiór ze strony słuchaczy i czytelników. Tam, gdzie pozwalają na to źródła, przytaczam opinie o kazaniach i ich twórcach.

$Z$ ewangelicznego punktu widzenia, kazanie to taka forma wypowiedzi duchownej, która związana jest ze zbawczą misją Kościoła, jaką prowadzi on na ziemi. Historycznie pierwszym typem nauczania kościelnego była homilia, stanowiąca popularny, budujący wykład Pisma Świętego. Polegała ona na odczytywaniu i wyjaśnianiu perykop ze Starego i Nowego Testamentu przy zachowaniu pełnej zgodności z tekstem biblijnym. Obok homilii występuje kazanie właściwe, którego przedmiotem staje się jednolity temat $z$ nauki wiary, omawiany na podstawie do-

\footnotetext{
${ }^{3} \mathrm{O}$ obywatelskiej działalności Kościoła katolickiego w czasach stanisławowskich pisali m.in.: A. J. Zakrzewski, Kształtowanie opinii publicznej w XVIII w. na przykładzie działalności kaznodziejskiej Michała F. Karpowicza (1774-1803) w: „Przegląd Humanistyczny”. R. 22: 1978, nr 12 (159), s. 53-66; Idem, Reforma Rzeczypospolitej w kaznodziejstwie oświeceniowym w: „Acta Universitatis Wratislaviensis", Nr 1368, Prace Literackie XXXI, Wrocław 1991, s. 145-154; J. Ziółek, Księża w szeregach jakobinów polskich, w: Zwycięstwo czy klęska? W 190 rocznicę powstania kościuszkowskiego. Praca zbiorowa pod red. H. Kocója, Katowice 1984, s. 76-90; Idem, Konstytucja 3 Maja. Kościelnonarodowe tradycje święta, Lublin 1991; Idem, Rola Kościoła katolickiego w formowaniu i funkcjonowaniu tradycji 3 Maja, w: Konstytucja 3 Maja w tradycji i kulturze polskiej, Łódź 1991, s. 491-515 (dla interesujących nas kwestii obie pozycje zbieżne); artykuły w pracy zbiorowej: Sukmana i krzyż. Studia z dziejów insurekcji kościuszkowskiej. Zagadnienia militarne i organizacyjne. Udział duchowieństwa. Legenda Naczelnika. Pod red. J. Ziółka, Lublin 1990; H. Dylągowa, Duchowieństwo katolickie wobec sprawy narodowej (1764-1864), Lublin 1983. Także prace autorki tego artykułu. Dziejom Kościoła katolickiego w epoce stanisławowskiej od strony organizacyjnej i pod kątem dokonujących się wtedy zmian wewnętrznych poświęcono liczne syntezy i rozprawy w prasie fachowej, które ukazały się na przestrzeni dwustu lat. Tu wymienię tylko najnowsze i najbardziej nowoczesne ujęcia: S. Litak, J. Skarbek, Kościół na ziemiach polskich 1715-1848, w: Historia Kościoła, kom. red. L.J. Rogier i in., Warszawa 1987, t. 4: 1715-1848, s. 393-524; J. Kłoczowski, Dzieje chrześcijaństwa polskiego, t.1, Paryż 1987; J. Kłoczowski, L. Müllerowa, J. Skarbek, Zarys dziejów Kościoła katolickiego w Polsce., Kraków 1986. Ponadto prace, rozprawy i artykuły z dziejów poszczególnych zgromadzeń zakonnych.

${ }^{4} \mathrm{H}$. Dziechcińska, Oglądanie i słuchanie w kulturze dawnej Polski, Warszawa 1987, s. 10.
} 
wolnie wybranych fragmentów Biblii. Będąc luźniej związane ze ścisłym nałuczaniem kościelnym - w przeciwieństwie do homilii - kazanie tematyczne zaczęło łączyć w sobie obok tradycyjnych elementów ewangelicznych motywy naukowe $i$ artystyczne. W swym historycznym rozwoju osiągnęło ono szczyty możliwości intelektualnych, zastępując traktaty teologiczne i rozprawy religijne ${ }^{5}$. Niejednokrotnie bywało przeznaczone dla elity umysłowej epoki, w przeciwieństwie do zrozumiałych homilii i postylii, odpowiadającym potrzebom niewykształconego odbiorcy. Różne formy oratorstwa duchownego stały sie podstawowymi elementami procesu komunikacyjnego, jaki w ciągu dziejów funkcjonował $i$ doskonalił się wewnątrz wspólnoty Kościoła.

Obcowanie ze Stowem Bożym wymagało znacznego przygotowania, trud pośrednictwa między Stwórcą a wiernymi spoczywał na barkach kapłanów, którzy stali się ekspertami i mistrzami w sztuce komunikowania religijnego. Ich dziatania poddane zostały jednak od początku sztywnym normom i wzorom zachowań. Z kościelnego punktu widzenia zasadniczym celem oratorstwa duchownego jest dążenie do przekonania słuchacza o słuszności przedstawianych prawd religijnych, wpłynięcie na jego wolę i serce. Kazanie to komunikat skierowany przede wszystkim do uczuć, nie zaś intelektu odbiorcy ${ }^{6}$. W interesującym ras okresie podlegało ono konkretnym wskazówkom, jakie z normatywnego punktu widzenia zachowały swą aktualność po dzień dzisiejszy. Nadawały one niektórym warstwom kazania charakter pona Jczasowy, uniwersalny, gdyż zgodnie z nauką Kościoła taki charakter maja podstawowe dla chrześcijaństwa źródła prawdy i wiary - Pismo Święte, Tradycja, dzieła Ojców i Doktorów Kościoła, dekrety kolejnych soborów i uchwały synodów prowincjonalnych ${ }^{7}$. Ta szczególna warstwa religijnego ko-

${ }^{5}$ Homiletyka duszpasterska. Zbiorowy podręcznik nauki kaznodziejstwa dla polskiego kleru, Kielce 1935, s. 6, 22; A Jougan, Homilie polskie od czasów najdawniejszych po dobę obecną. Szkice bibliograficzne i krytyczne, Lwów 1902; M. Korolko, Uwagi o genologii kazania politycznego w Polsce XVI w., w: Kultura i literatura dawnej Polski. Studia, Warszawa 1968, s. 157-158.

${ }^{5}$ J.B. Hédouin, Zasady wymowy świętej. Ed. z wyjątkami kaznodziejów polskich pomnożona. Warszawa 1819 , s. 5-7, 52-57, 103. Kwestie wpływu kazania na życie wiernych porusza bardzo bogata literatura dotycząca teorii i praktyki kaznodziejskiej.

Miejsce działalności kaznodziejskiej w życiu Kościoła wyznaczył Sobór Trydencki (1514-1563). Obradujący Ojcowie zalecili oczyszczenie kaznodziejstwa z wszelkich nieprawidłowości. Podstawą dla głoszenia Słowa Bożego stać się miało Pismo Święte (w formie zaaprobowanej przez Sobór Wulgaty), Tradycje oraz dzieła Ojców Kościoła. Podkreślono obowiązek głoszenia kazań przez biskupów i proboszczów w niedziele oraz święta. Wynikało to z dyskusji co do istoty kaznodziejstwa, ktöre według I Listu Świętego Pawła do Koryntian stanowi obowiązek biskupi. Wprowadzeniu wszystkich reform w życiu przewodzić miały synody prowincjonalne i diecezjalne, którym Sobór Trydencki nadał szczególne znaczenie. Uchwały Soboru Trydenckiego zostały przyjęte w Rzeczypospolitej przez króla Zygmunta Augusta wraz z senatem na sejmie w Parczewie w roku 1564. Kościół polski zaakceptowat je na specjalnym synodzie prymacjalnym w 1577 r. Ustawodawstwo soborowe przenikało do prawodawstwa poszczególnych krajów powoli i stopniowo. Badacze sugerują, że w Rzeczypospolitej ten niezwykle złożony proces zachodził do końca XVIII stulecia. Jego inicjatorami byli przede wszystkim popierający reformę poszczególni biskupi i synody, które funkcjonowały szczególnie energicznie w drugiej połowie XVI i pierwszej XVII wieku. J. Delumeau, Reformy chrześcijaństwa w XVI i XVII w., t. 2: Katolicyzm między Lutrem a Wolterem, Warszawa 1986; M. Jabłoński, Teoria duszpasterska (wiek XVI-XVIII), w: Dzieje Teologii katolickiej w Polsce, t. 2, cz.1, poświęcone historii Kościoła w Polsce. 
munikatu dotykała niezwykle delikatnej sfery sacrum i dla ludzi wychowanych w wierze stanowi niezmienną od wieków wspólnotę znakową. Od początków swojego istnienia literatura chrześcijańska podporządkowana została antycznej retoryce. W związku z tym kazanie jako forma oratorstwa duchownego ulegało na przestrzeni wieków kolejnym teoriom wymowy ${ }^{8}$. W praktyce od strony literackiej stało się ono wypadkową dwóch funkcji - stałej (wynikającej z trwałości prawzoru literackiego Biblii) i zmiennej - zależnej od panującej w literaturze mody. Ale kazanie to nie tylko poddane określonym rygorom wewnętrznym słowo mówione czy następnie tekst drukowany - to także mówca i sposób jego komunikowania się z odbiorcą. Dlatego także sztuka gestykulacji i zachowania się na ambonie poddana została ścisłym zasadom retorycznym. Niejednokrotnie wystąpienie oratora kościelnego nabierało cech widowiska parateatralnego, w którym nie tylko słowa, ale i obraz odgrywały istotną rolę ${ }^{9}$ W zależności od konwencji epoki kaznodzieja mógł przyjmować pozę dobrodusznego nauczyciela ludu, wieszczącego przyszłość kapłana-proroka bądź orędownika walki. W procesie komunikacji religijnej, literackiej i społecznej ważne także było audytorium kaznodziei. Powinien on bowiem posługiwać się językiem tych, przed którymi głosił Ewangelię ${ }^{10}$. Według norm, które wypracował Kościół, to kapłan dostosowuje się do możliwości percepcji wiernych. Dodatkową cechą specyficzną kazania jest jego ścisłe podporządkowanie cenzurze duchownej. W przypadku kaznodziejstwa zakonnego nawet podwójnej: biskupa danej diecezji i przełożonego zgromadzenia. W ten sposób kazanie stawało się swoistym komunikatem, który nie stanowił prezentacji myśli autora i którego stopień indywidualizacji zależał najczęściej od talentu literackiego i oratorskiego twórcy dokonującego aktu swoistej interpretacji. Kaznodzieja nie tworzy bowiem nowej rzeczywistości, ale objaśnia prawdy oczywiste - dane od Boga, a potwierdzone nauką i autorytetem Kościoła. Znane są wypadki, gdy świetnie piszący duchowny nie sprawdzał się jako mówca, inny zdolnościami aktorskimi nadrabiał braki tekstu lub tekst zamawiał u kogoś trzeciego.

W epoce stanisławowskiej, podobnie jak w okresie staropolskim, szkoła była tą instytucją życia publicznego, która pełniła istotną rolę ośrodka inicjacji literackiej. Wyuczone w szkole kanony większość absolwentów powielała w późniejszym dorosłym życiu zarówno prywatnym, jak publicznym. Szkoły stwarzały więc warunki biernego i czynnego obcowania z literaturą ${ }^{11}$. Reformy edukacyjne 2. połowy XVIII wieku przygotowywały także młodzież do bardziej odpowiedzialnego życia

\footnotetext{
${ }^{8}$ M. Janik, Z dziejów wymowy w wieku XVII i XVIII, Lwów 1908 - przedstawia zmiany, jakie zachodziły w teorii retorycznej tego okresu; J. Pelczar, Zarys dziejów kaznodziejstwa w kościele katolickim. Cz. 2: Kaznodzieje polscy, Kraków 1896 - omawia także wpływ modnych teorii na literacką i retoryczną formę kazań w różnych epokach.

${ }^{9}$ H. Dziechcińska, op. cit, s. 44, 51.

${ }_{10}$ A. Guriewicz, Problemy średniowiecznej kultury ludowej, Warszawa 1987, s. 16-22.

" K. M. Dmitruk, Publiczność południa XVIII wieku w: Kultura literacka połowy XVIII wieku w Polsce. Studia i szkice. Pod red. T. Kostkiewiczowej, Wrocław 1992, s. 72-73. Kwestiom „publiczności” poświęcili swe rozważania J. S. Bystroń, Publiczność literacka, Lwów 1938, Publiczność literacka, red. S. Żółkiewski, M. Hopfinger, Wrocław 1982; Publiczność literacka i teatralna w dawnej Polsce, Praca zbiorowa pod red. H. Dziechcińskiej, Warszawa 1985.
} 
obywatelskiego. W ten sposób szkoły formowały potencjalnego odbiorcę literackiego i człowieka wrażliwego na potrzeby kraju. Określone cele stały także przed szkołami zakonnymi, które od czasów reform pijara Stanisława Konarskiego z lat czterdziestych i pięćdziesiątych XVIII w. musiały zweryfikować swe założenia poznawcze, edukacyjne i wychowawcze. W kaznodziejstwie systematycznie odchodzono od pojmowania sztuki wymowy jako zbioru reguł, co było charakterystyczne dla stulecia XVII. Założenia retoryczne podporządkowano aktualnym potrzebom Kościoła jako wspólnoty wiernych. Do treści kazań włączono wątki obywatelskie. Postulowano oratorstwo proste, zrozumiałe, a przez to społecznie użyteczne. Sugerowano odchodzenie od przerośniętej i wynaturzonej erudycji humanistycznej, której nadużywanie ośmieszało Kościół w oczach jego przeciwników. Reformatorzy duchowni z dużą powściągliwością odnosili się także do głębokiego, teologiczno-traktatowego kaznodziejstwa potrydenckiego, mając świadomość, że powierzchowne filozoficzne przygotowanie większości duchowieństwa nie pozwala mu wziąć udziału w tego typu dyskusjach. Szczególne osiągnięcia na niwie kaznodziejskiej miały seminaria duchowne prowadzone przez księży pijarów, jezuitów i misjonarzy, które wykształciły najwybitniejszych mówców duchownych epoki stanisławowskiej'12. Obok szkół zakonnych, w których preferowano konkretne wzorce kaznodziejskie, wyraźny wpływ na kształt oratorstwa duchownego w 2 . poł. XVIII w. mieli niektórzy przedstawiciele episkopatu polskiego. Najbardziej światli, wrażliwi na los Kościoła i państwa biskupi w listach pasterskich skierowanych do podległego sobie duchowieństwa zalecali kaznodziejstwo oparte na popularnych, przystępnych i sprawdzonych wzorach chrześcijańskich. Brat królewski biskup płocki, a potem prymas Michał Jerzy Poniatowski, biskup wileński Ignacy Józef Massalski, biskup włocławski i pomorski Józef Ignacy Rybiński oraz administrator chełmski i lubelski Wojciech Skarszewski rozwinęli szeroką działalność duszpasterską ${ }^{13}$. Oprócz wskazówek i zaleceń, popierali szeroką akcję wydawniczą, która dotyczyła łłumaczeń i edycji zbiorów homilii wybitnych kaznodziejów katolickich także polskich. Biskupi bywali także mecenasami i sponsorami dla zdolnych przedstawicieli podiegłego im duchowieństwa ${ }^{14}$.

12 S. Kot, Historia wychowania. Wyd. 2, zmien. i pomn., Lwów 1934, t. 1, s. 384-397; J. Buba, Collegium Nobilium, w: Pijarzy w kulturze dawnej Polski, Kraków 1982, s. 83-103; S. Konarski, Ustawy szkolne, z jęz. lac. przeł. W. Germain, przyp. zaopatrzył J. Czubek, wstępem poprzedził S. Kot, Kraków 1925.

${ }^{13}$ M. J. Poniatowski, Rozporządzenia i pisma pasterskie za rządów... do diecezji płockiej wydane, Warszawa 1785, t. 1-4. Tu liczne fragmenty dotyczące zadań kaznodziejów i roli kazań. M. Grzybowski, Kościelna działalność Michała Jerzego Poniatowskiego biskupa płockiego 1773-1785, Warszawa 1983, s. 137; [T. Husarzewski] Książka jubileuszowa na diecezję wileńską z rozkazu jaśnie oświeconego pasterza roku 1776 wydana, Wilno [1776], tu liczne fragmenty dotyczące problematyki kaznodziejskiej; I. Rybiński, Rozporządzenia pasterskie na diecezję kujawską i pomorską [B.m.] 1178 fragmenty dotyczące kazań; J. Wysocki, Józef Ignacy Rybiński, biskup włocławski i pomorski 1777-1806. Zarys biograficzny na tle rządów diecezją. Rzym 1967, s.87, 99-100; W. Leszczyc Skarszewski, Rozporządzenie pasterskie na diecezję chełmską i lubelską roku 1792. [B.m.r.]

${ }^{14} \mathrm{~Np} . \mathrm{z}$ inicjatywy M. J. Poniatowskiego wyszły Kazania niektóre [...] księży diecezji płockiej, Warszawa 1785, wcześniej, być może z inicjatywy biskupa krakowskiego, Kajetana Sołtyka lub któregoś z jego pomocników ukazały się Kazania kaznodziejów katedralnych krakowskich miane 
Literatura kaznodziejska towarzyszyła przez stulecia wszelkim okolicznościom życia człowieka - narodzinom, ślubom, rocznicom, powołaniom zakonnym, śmierci. Towarzyszyła także okolicznościom życia publicznego - sejmom, elekcji nowego monarchy, trybunałom, wszelkim wystąpieniom zbrojnym, wojnom i powstaniom. Ze względu na reformy wychowania podjęte w czasach stanisławowskich, literatura kościelna tego okresu, podobnie jak innego typu piśmiennictwo, wykazuje wyraźny wzrost tíeści obywatelskich w miejsce charakterystycznej dla epoki staropolskiej indywidualnej twórczości panegirycznej. Równocześnie dostrzega się wyraźną dbałość hierarchii kościelnej o właściwy styl, poprawność językową i odpowiednią treść różnego typu twórczości kaznodziejskiej, która kierowana była do różnego typu odbiorcy.

W czasach stanisławowskich ukazało się drukiem około 200 kazań okolicznościowych związanych z konkretnym wydarzeniem politycznym bądź społecznym, podobna liczba mów pogrzebowych oraz około 130 tomików homilii, czyli popularnego tłumaczenia fragmentów Pisma Świętego, co stanowi blisko 2500 kazań dotyczących ścisłej problematyki religijnej ${ }^{15}$. Twórczość kaznodziejska, która przybrała formę druku, stanowiła zaledwie znikomy procent słowa mówionego. Przyjrzyjmy się różnym typom twórczości kaznodziejskiej ze względu na twórców, inicjatorów i odbiorców tego typu literatury.

Najmniej skomplikowana wydaje się sytuacja kaznodziejstwa pogrzebowego. Należało ono do twórczości panegirycznej, najczęściej publikowano je na wyraźne życzenie, za zgodą i na koszt rodziny osoby zmarłej. Im wyższy był status społeczny i pozycja majątkowa zmarłego, tym słynniejszy mówca duchowny jeden lub kilku głosiło i publikowało swoje wystąpienia. W kazaniach takich starano się podkreślić zalety osobiste, religijne i obywatelskie danej osoby. Eksponowana w większości oracji pogrzebowych odpowiedzialność za losy kraju była wyrazem tendencji, jakie panowały w wychowaniu i piśmiennictwie epoki. Szczególnego znaczenia nabierały kazania na pogrzebach osób wybitnych. Prezentowane w nich sylwetki zmarłych urastały do symboli poświęcenia rodzinnego, prawowierności religijnej i patriotyzmu. Panegiryzm łączył się z dydaktyzmem. Podkreślany mocno katolicyzm miał szczególny wydźwięk w czasach racjonalizacji życia duchownego. Odbiorcą takich kazań w ich formie oralnej byli uczestnicy obrządku pogrzebowego, w formie drukowanej najczęściej rodzina i przyjaciele zmarłego. Szczególną roię w systemie społecznej komunikacji pełniły kazania pogrzebowe z okresu powstania kościuszkowskiego w $1794 \mathrm{r}^{16}$ Dotyczyły one bohatera zbio-

w niedziele całego roku w katedrze krakowskiej, t. 1-2, Kraków 1782-1783. O obu zbiorach wspomina A. Jougan, Nasze kazania zbiorowe, Lwów 1911, s. 55-56, 68-71. Także biskup wileński Ignacy Massalski odznaczał się wyjątkową dbałością o druk kazań duchownych ze swojej diecezji (np. M. F. Karpowicza, W. Kalińskiego $i$ in.).

${ }_{15}$ Dane na podstawie Estreichera, Nowego Korbuta, współczesnych katalogów wydawniczych, zapowiedzi i reklamy prasowej. Część odnalezionych przeze mnie kazań nie była odnotowana wcześniej w żadnych bibliografiach.

${ }_{16}$ Podczas powstania opublikowano około dwudziestu kazań. Obok mów pogrzebowych były to pobudki wojenne, kazania dziękczynne. Jedno z nich - Michała Franciszka Karpowicza przetłumaczono nawet na język litewski, by w ten sposób poszerzyć ewentualny krąg czytelników i słuchaczy. Wszy- 
rowego, jakimi byli polegli w walkach powstańcy oraz ludność cywilna. W kazaniach, które wygłaszano $w$ trakcie czterdziestogodzinnych nabożeństw pogrzebowych, kreowano postać zbiorowego rycerza, nieustraszonego bojownika za wolność ojczyzny. Nabożeństwa takie odbywały się na wyraźne żądanie władz insurekcyjnych, ale z inicjatywy zwierzchności kościelnej. Wystrój świątyń dostosowywano do ceremonii pogrzebowej. Na centralnie ustawionym katafalku, wśród laurów zwycięstwa umieszczano odpowiednie cytaty ze Starego Testamentu, które podkreślały sakralny charakter spełnionej przez poległych ofiary ${ }^{17}$. Całość była tak reżyserowana, aby nie doprowadzić do nieprzewidzianych zachowań uczestników nabożeństwa-spektaklu. Kod nabożeństwa żałobnego, ze swoją symboliką słowno-obrazową wyrastał z tradycji kultury sarmacko-chrześcijańskiej i był zrozumiały dla wszystkich uczestników ceremonii. Wobec kazania pogrzebowego słuchacz przyjmował określoną postawę obyczajowo-rytualną, wynikającą z utrwalonej przez stulecia retorycznej funkcji takiej oracji. Równocześnie jednak kazania insurekcyjne zawierały silne intencje patriotyczne, współuczestnicząc w sakralizacji insurekcji i współtworząc jej mit. Wygłoszone wtedy oracje drukowano następnie na koszt władz powstania w podległych im oficynach, co świadczy o tym, że spełniały one oczekiwania przywódców insurekcji. Autorami takich mów byli duchowni popierający walkę z wrogiem zewnętrznym, tj. Rosją i Prusami oraz domowymi zdrajcami, tj. przywódcami konfederacji targowickiej. W przypadku tych specyficznych mów krąg odbiorców wyraźnie się poszerzał. Kazania kierowano nie tylko do rodzin poległych, ale także do uczestników powstania, którym prezentowano w ten sposób wzorce bohaterstwa i poświęcenia.

Przyjrzyjmy się z kolei, jaką rolę w procesie społecznej i literackiej komunikacji pełniły kazania popularne, których ilość przewyższała produkcję innych typów oracji duchownych. Na podstawie rozporządzeń biskupich oraz wstępów do niektórych zbiorów kazań wnioskować możemy, że inicjatorami szeroko zakrojonej akcji wydawniczej i translatorskiej byli właśnie najbardziej światli przedstawiciele polskiego episkopatu doby stanisławowskiej. W drukarni prymasowskiej w Łowiczu ukazało się wiele tomów kazań obcych i polskich. Przełożeni zakonni promowali oratorów ze swojego zgromadzenia, chociaż drukowali także dziełka innych mówców. Autorów wartościowych kazań popularnych wyławiano w środowiskach dworów biskupich dzięki obowiązkowi dorocznego dostarczania kilku kazań do wglądu władzom kościelnym ${ }^{18}$. Dla wielu autorów druk ich oracji był nie tylko wielkim wyróżnieniem, ale otwierał drogę do kariery kościelnej. Wydaje się jednak, że

stkie znane kazania mocno akcentowały wątki patriotyczne i narodowowyzwoleńcze. Operowały frazeologią demokratyczno-rewolucyjną, ale równocześnie broniły powstania przed zarzutami jakobinizmu na wzór francuski. Najbardziej znane kazania pogrzebowe z okresu insurekcji to kazania Michała Karpowicza, Ignacego Witoszyńskiego, Marcina Gumkowskiego, Jana Nepomucena Adriana Dębskiego, Antoniego Stanisława Lewkowicza.

17 Prasa powstańcza opisywała przebieg takich nabożeństw i wystrój kościołów np. „Gazeta Wolna Warszawska”, R. 1794, nr 3: 3 V, „Korespondent Narodowy i Zagraniczny”, R. 1794, nr 44: 3VI, ibidem, R. 1794, nr 46: 10 VI - dodatek, „Gazeta Rządowa”, R. 1794, nr 96: 8 X.

${ }^{18}$ M. J. Poniatowski, op. cit, t.4, s. 92-93, 102-104. 
odbiór tego typu kazań w formie książkowej napotykał spore trudności. Analiza ogłoszeń i reklam prasowych dowodzi, że zbiory homilii ukazywały się nawet $w$ cyklu kilkuletnim, szczególnie gdy edycja była wielotomowa (6-8 tomów) i niekiedy poprzedzała ją sybskrypcja. Wydanie dwutomowe średnio kosztowało ok. 8-10 złp, ośmiotomowe dochodziło do zł 27. Powtarzające się wielokrotnie w kilkuletnich nawet odstępach czasowych zachęty do kupna świadczą o zaleganiu tego typu produkcji w składach księgarskich. Niewiele pomagało przedstawienie autorów kazań jako wybitnych oratorów kościelnych, których wystąpienia przyciągały wiernych, a pełne godności i miłosierdzia życie prezentowano jako godne naśladownictwa ${ }^{19}$. Wydaje się więc, że o ile odbiorcą oralnej formy kaznodziejstwa popularnego byli po prostu ci wszyscy, którzy uczestniczyli w mszy świętej, o tyle w formie drukowanej w większości wypadków trafiały do odbiorcy duchownego, dla którego stawały się zaaprobowanym przez władze kościelne wyborem gotowych do wygłoszenia tekstów. Cechą bowiem homilii jest ich dostosowanie do odpowiedniego fragmentu Biblii, mogą więc być wygłaszane $w$ dowolnym kościele, przez dowolnego kaznodzieję, w dowolnym czasie historycznym. A mamy przykłady, że najwspanialsze wzorce funkcjonowały nawet przez stulecia - jak popularne kazania Piotra Skargi, czy postylle Jakuba Wujka. Władze kościelne zalecały duchowieństwu korzystanie z gotowych wzorców, wskazywały nawet najwybitniejszych autorów ${ }^{20}$. Biskupi wychodzili bowiem z założenia, że dla dobra atakowanego z różnych stron Kościoła korzystniejsze jest posługiwanie się sprawdzonymi wzorami niż fałszowanie Słowa Bożego przez niedouczonych księży. Tego typu zbiory były również obowiązkową lekturą dla młodzieży przygotowującej się do stanu duchownego. Na zajęciach z kaznodziejstwa analizowano przykłady różnego typu oratorstwa ${ }^{21}$. Biblioteki kościelne, zakonne i seminaryjne winny gromadzić tego typu literaturę 22 . Biskupi przeprowadzający wizytacje przywiązywali dużą wagę do tego, czy proboszczowie dysponują odpowiednimi zbiorami kazań. Podtytuły i wstępy do niektórych wydań kazań popularnych sugerują, że publikowano je także pod kątem wiernych, którzy z różnych powodów nie mogli uczestniczyć w mszy świętej, ale chcieliby zapoznać się z tekstem przypadającej na dany dzień liturgii słowa. Analiza księgozbiorów religijnych szlachty krakowskiej XVIII w. dowodzi, że w okresie Oświecenia wyraźnie zmalało zainteresowanie dla tego typu literatury, w tym także kazań, których liczba wydatnie zmniejszyła się w po-

${ }^{19}$ Wnioski takie wysuwam na podstawie analizy ogłoszeń prasowych w „Gazecie Warszawskiej” $i$ „Gazetach Wileńskich”, które to tytuły ukazywały się regularnie w epoce stanisławowskiej. Ze względu na dużą ilość przykładów rezygnuję z ich przytaczania. Reklamie wydawniczej i księgarskiej poświęciła swą pracę D. Hombek, Reklama wydawnicza i księgarska w "Gazecie Warszawskiej” w latach 1764-1785, Kielce 1988.

${ }^{20}$ M. J. Poniatowski, op. cit, t. 1, s. 421, t. 3, s. 177-185; J. Rybiński, op. cit, s. 45; J. Wysocki, op. cit, s. 61-62.

${ }^{21}$ J. Rybiński, op. cit, s. 17; J. Wysocki, op. cit, s. 135. Szczególną wagę do głoszenia Słowa Bożego przywiązywał Stanisław Konarski, reformując szkolnictwo pijarskie. Trzynasty rozdział Ordinationes visitiationis apostolicae... A.D. 1753 poświęcony jest właśnie kwestiom kaznodziejskim. Polski tekst Ordynacji w: S. Konarski, Ustawy szkolne.

${ }_{22}$ J. Kracik, Duszpasterstwo parafialne w dekanacie Nowa Góra w pierwszej połowie XVIII w., w: Studia kościelno-historyczne, Lublin 1977, t. 2, s. 178. 
równaniu z epoką saską ${ }^{23}$. Także literatura dydaktyczna polskiego Oświecenia propagująca moralno-obyczajowe wzorce zachowań podkreślała, że w bibliotekach domowych, a tym bardziej kościelnych, powinny znajdować się zbiory kazañ ${ }^{4}$. Budującego przykładu dostarczał sam monarcha, który nie tylko uczestniczył we wszystkich ceremoniach kościelnych, promował i inspirował mówców duchownych, ale także nabywał i czytywał kazania rodzime, w oryginale zaś popularne w Polsce oracje Jeana Christiana Massillona i Louisa Bourdalaue. Niektóre tomiki towarzyszyły mu nawet na wygnaniu w Petersburgu po upadku państwa w $1795 r^{25}$

Podobnie jak w przypadku druku homilii, zmiana odbiorcy następowała także w przypadku tzw. kazań wiejskich i miejskich. Szczególnie te pierwsze były popularne w Rzeczypospolitej ze względu na rustykalny charakter jej społeczeństwa i kultury. W formie oralnej kazania te skierowane były przede wszystkim do chłopów pańszczyźnianych - preferując idealistyczne, paternalistyczne zasady stosunków na wsi. Kaznodzieje apelowali także do osiadłej na wsi szlachty, nawołując ją do ojcowskiej opieki nad chłopem. Z zasady nie poruszali jednak żadnych tematów mogących zachwiać strukturami społeczno-ustrojowymi państwa. Wręcz przeciwnie, mocno akcentowali zgodnie z ewangelicznymi przykładami idee posłuszeństwa i pracy. $W$ formie drukowanej kazania takie zmieniały podstawowego odbiorcę. Zarówno chłopi, jak i część ubogiej szlachty nie byli wszakże piśmienni. Kazania natomiast stawały się natychmiast mowami wzorcowymi dla innych kaznodziejów, którzy pracowali w parafiach wiejskich. Najlepszym przykładem pozostają słynne "mowy do rolników" jednego z najwybitniejszych kaznodziei stanisławowskich Wilhelma Kalińskiego. Były to najczęściej drukowane w XVIII stuleciu kazania, powielane także $w$ wieku $\mathrm{XIX}^{26}$. Całe fragmenty tych kazań odnaleźć możemy w drukowanych wiejskich kazaniach innych oratorów religijnych epoki stanisławowskiej, choć nikt nie przyznawał się do plagiatu ${ }^{27}$.

Podobnie wyglądała sytuacja z parafialnym kaznodziejstwem miejskim. W formie oralnej skierowane ono było do wiernych uczestniczących w nabożeństwie.

${ }^{23} \mathrm{H}$. Bogdanow, Piśmiennictwo religijne w księgozbiorach szlachty krakowskiej w XVIII wieku jako wyraz jej zainteresowań czytelniczych, w: Problemy kultury literackiej polskiego oświecenia, Wroctaw 1978, s. 115-116.

${ }^{24}$ J. K. Kossakowski, Ksiądz pleban. Warszawa 1786, s. 21, 38, 103.

${ }^{25}$ Biblioteka Stanisława Augusta na Zamku Królewskim. Dokumenty. Oprac. J. Rudnicka w: „Archiwum Literackie”, t. 26: 1988, s. 71, 138, 140, 143.

${ }_{26}$ Wilhelm Kaliński - misjonarz, protegowany biskupa wileńskiego Ignacego Massalskiego, był autorem różnego typu kazań. Wśród jego twórczości drukowanej znalazły się mowy, jakie wygłoszono do włościan w dobrach referendarza litewskiego, Pawła Brzostowskiego, w czerwcu i październiku 1779 oraz w maju 1780 r. Wydano je jako druki samodzielne zaraz po ich wygłoszeniu oraz przynajmniej dwukrotnie pod wspólnym tytułem Mowy do rolników, w zbiorowym wydaniu dzieł Kalińskiego z 1791 i w edycjach dziewiętnastowiecznych jego kazań. Innym wybitnym mówca kościelnym, który nawiązywał do kwestii chłopskich był zwolennik fizjokratyzmu - Michał Franciszek Karpowicz. O jego kazaniach m.in. M. Ślusarska, Michał Franciszek Karpowicz (1744-1803), w: Pisarze polskiego Oświecenia. Pod red. T. Kostkiewiczowej i Z. Golińskiego, t. 2, Warszawa 1994, s. 74-98.

${ }^{27} \mathrm{~F}$ Siarczyniski, Kazania... zebrane z pozostałych jego rękopisów (przekł. J. A. Kamińskiego), Lwów 1832. W Kazaniu $\vee W$ Dzjeń Bożego Narodzenia odnajdujemy całe, niezmienione fragmenty mowy Kalińskiego O pociechach stanu rolniczego (wygłoszona w Pawłowie 29 czerwca 1779). 
Do czasów Sejmu Wielkiego (1788-1792) obracało się ono głównie w sferze moralnej. W literaturze kaznodziejskiej funkcjonował bowiem jeszcze do końca XVIII w. motyw miasta jako siedliska bezprawia, zepsucia obyczajów i rozwiązłości. Mieszkańcy miast, wielokrotnie obcego pochodzenia, ulegali według duchowieństwa katolickiego zgubnemu zachodniemu nowinkarstwu, nie chcieli uczęszczać do kościołów i słuchać kazañ ${ }^{28}$. Z obojętnością religijną mieszkańców Warszawy walczyli kolejni rządcy diecezji oraz prymas Michał Poniatowski ${ }^{29}$. Prowadzono akcje rekolekcyjne, misyjne, kaznodzieje specjalizowali się $w$ głoszeniu kazań także w języku niemieckim, francuskim i włoskim, zapraszano księży z zagranicy. Episkopat, a także sam król Stanisław August, promował i nagradzał oratorów duchownych szczególnie zaangażowanych w moralne odrodzenie stolicy. Dla takiego kaznodziei zaszczytem była obecność monarchy i dworu na wygłaszanym kazaniu, a następnie umożliwienie jego druku ${ }^{30}$. Wydrukowane kazania nabierały charakteru wzorcowego podobnie jak oracje wiejskie. Ich głównym czytelnikiem i odbiorcą stawała się młodzież przygotowująca się do stanu duchownego oraz księża związani ze środowiskiem miejskim. Kazania parafialne „Apostoła Warszawy", proboszcza parafii św. Andrzeja przy kościele św. Krzyża, Tomasza Grodzickiego, swój wzorcowy charakter zachowały jeszcze w wieku XIX, kiedy przedrukowywano je w kilkutomowych edycjach zalecając duchowieństwu do szczególnego studiowania ${ }^{31}$.

Trudno ocenić rzeczywisty wpływ oralnego parafialnego kaznodziejstwa na wiernych, gdyż wypowiedzi dotyczące kazań popularnych pochodzą nie od bezpośredniego ich słuchacza, ale od instytucji i osób starających się wpływać odgórnie na obraz polskiego Kościoła katolickiego. To hierarchia duchowna, środowisko dworskie i docierająca do elit intelektualnych prasa bierze udział w promowaniu określonych mówców i odpowiedniego dla Kościoła typu kaznodziejstwa. Także pisarze dydaktyczni - jak znany kaznodzieja, Józef Kazimierz Kossakowski, późniejszy biskup inflancki i targowiczanin stracony w dniach powstania kościuszkowskiego - w swych utworach preferowali postać dobrego duszpasterza, gorliwego nauczyciela ludu. Dla zwierzchności duchownej dowodem popularności danego mówcy była liczba wiernych uczestniczących w nabożeństwach, ale obserwacja taka możliwa okazywała się tylko w ośrodkach bliskich rezydencjom biskupim. Druk homilii zasadniczo wpływał na zmianę ich odbiorcy. Nie był nim członek danej wspólnoty parafialnej, ale przede wszystkim środowiska kościelne i w mniejszym stopniu przedstawiciele tych grup społecznych, które posiadały umiejętność czytania - szlachta, arystokracja, wykształcone mieszczaństwo, wreszcie środo-

\footnotetext{
${ }^{26}$ B. Urban, Ideał katolika w świetle polskich kazań franciszkańskich w latach 1765-1795, Lublin 1971, s. 146 (maszynopis pracy doktorskiej).

${ }^{29}$ 1. Witoszyński, Kazanie na pogrzebie... Michała Jerzego Ciołka Poniatowskiego... dnia 18 sierpnia Roku Pańskiego 1794, Warszawa 1794, s. 15-16.

${ }^{30} \mathrm{O}$ uczestnictwie króla w nabożeństwach, nagradzaniu kaznodziejów różnymi odznaczeniami, w tym medalem „Merentibus", a następnie druku kazań informowała na bieżąco „Gazeta Warszawska”.

${ }^{31}$ T. Grodzicki, Mowy parafialne miane w Warszawie w kościele św. Jędrzeja, wyd. 2, t. 1-4, Kraków 1883-1884.
} 
wiska zawodowo związane z literaturą i często równocześnie z Kościołem - pisarze, poeci, dziennikarze. Ponowne, czy też kolejne odczytywanie spisanych już kazań „wzorcowych” zamykało ich specyficzny obieg. Znikomość materiałów źródłowych zdaje się sugerować, że w przypadku konkretnych, zamkniętych społeczności parafialnych - wiejskich czy miejskich - trudno mówić o aktywnej postawie odbiorców kazań wobec ich twórców i głosicieli, o próbach świadomego, publicznego formułowania opinii i wywierania presji na duchownych. W takiej wspólnocie kapłan z reguły cieszył się wysokim autorytetem. Ewentualne opinie i zdania krytyczne wyrażano raczej w kręgach rodzinnych i przyjacielskich, nie docierały one do odpowiednich instytucji życia publicznego, nie były głosem „publiczności", lecz najczęściej indywiduainą reakcją na niezrozumiałe lub naganne zachowanie księży $y^{32}$.

Inaczej rzecz się miała z okolicznościowymi kazaniami nastawionymi na aktualne problemy kraju. W czasach stanisławowskich były to: kazania sejmowe, które wygłaszano na otwarcie, zamknięcie i w trakcie trwania obrad parlamentu, kazania trybunalskie, które w podobny sposób funkcjonowały w związku z pracami najwyższej sądowej instancji szlacheckiej, jaką był Trybunał Koronny Litewski, kazania dworskie, które towarzyszyły wszystkim ważnym uroczystościom królewskim - urodzinom, imieninom, rocznicy elekcji i koronacji Stanisława Augusta. Powstawały także kazania związane z wielkimi politycznymi wydarzeniami epoki stanisławowskiej. Były to obrady Sejmu Wielkiego, Konstytucja 3 Maja, powstanie kościuszkowskie, I, II, III rozbiór kraju i upadek państwa. Wygłaszane we wszystkich tych okolicznościach mowy duchowne zachowywały główne cechy oracji kościelnej - a więc zgodność z Pismem Świętym, Tradycją, dziełami wielkich myślicieli Kościoła. Jednak w swej pozaewangelicznej wykładni nawiązywały do oficjalnej okolicznościowej literatury politycznej, bogato czerpały z myśli publicystycznej oraz modnej filozofii epoki, ale tylko tej, która nie zagrażała strukturom państwa i Kościoła. Podobnie jak inne rodzaje literatury okresu Oświecenia kaznodziejstwo okolicznościowe poddawało się procesowi „upolitycznienia”, co było charakterystyczną cechą literatury tego okresu ${ }^{33}$. Kazania takie propagowały ideały moralnego odrodzenia narodu, głosiły hasła oświeceniowego patriotyzmu, nowoczesnego monarchizmu i użyteczności społecznej wszystkich stanów. Nie formu-

\footnotetext{
${ }^{32}$ Zdarzenie takie opisuje w swych wspomnieniach Franciszek Karpiński. Opowiada, jak starszy brat, który był w klasie retoryki i przygotowywał się do stanu duchownego, głosił kazania dla popisu w izbie rodziców. Dla zabawy pozwolono i młodszemu wygłosić improwizowane kazanie. Ku uciesze zgromadzonych, operując zlepkiem oderwanych stów i mocno bijąc dłonią w stolik, zastępujący ambonę, dziecko sparodiowało postawę parafialnego kapłana, jaką obserwowało, uczestnicząc wraz z rodzicami w nabożeństwach. (F. Karpiński Historia mego wieku i ludzi, z którymi żyłem. Oprac. R. Sobol, Warszawa 1987, s. 32). Józef Drzewiecki pisze natomiast, że jako dziecko był świadkiem, jak w Krzemieńcu ksiądz misjonarz usiłował wpłynąć w patetycznej formie na jednego z wiernych, który przybył do kościoła nietrzeźwy, przez co naraził się tylko na śmieszność wobec uczestników mszy, których bawiła rozgrywająca się scenka - J. Drzewiecki, Pamiętniki (1772-1852), wyd. S. Pawlicki, Kraków 1891, s. 4-5.

${ }^{33}$ I. Stasiewicz-Jasiukowa, Człowiek i obywatel w piśmiennictwie naukowym i podręcznikach polskiego oświecenia, Wrocław 1979, s. 12.
} 
łowały konkretnych planów naprawy, gdyż zgodnie z zasadami oratorstwa kościelnego poruszały się przede wszystkim w sferze etycznej. Operowały jednak zrozumiałymi i wspólnymi dla ludzi Oświecenia słowami-kluczami, jak: miłość ojczyzny, prawo, sprawiedliwość, własność, edukacja, itp. Stanowiły więc komunikat dla określonych środowisk otwarty i jasny mimo swego religijnego charakteru. Głoszący tego typu kazania oratorzy duchowni stanowili grupę specyficzną. Znaleźli się w niej najwybitniejsi kościelni mówcy epoki - jak „Massillon polski” Michał Franciszek Karpowicz czy późniejszy biskup wileński Jan Nepomucen Kossakowski lub królewski kaznodzieja Ignacy Witoszyński. Byli wśród nich słabsi mówcy lecz popularni pisarze - poeta Jan Paweł Woronicz w przyszłości prymas Królestwa Polskiego, czy znawca współczesnej myśli pedagogicznej Wilhelm Kaliński. Kazania okolicznościowe tworzyli też mówcy kościelni o mniejszym prestiżu i sławie. Grupę tę dopełniał zestaw autorów na co dzień nie związanych z amboną, lecz czynnych na polu nauki, edukacji i literatury oraz polityki - Karol Wyrwicz, Kajetan Skrzetuski, Hugo Kołłątaj, Józef Rogaliński. Obok nich znaleźli się księża, których nazwiska przetrwały w historii dzięki ogłoszeniu jednej zaledwie okolicznościowej mowy dotyczącej aktualnych problemów kraju. Są w tej grupie ludzie o wszechstronnym wykształceniu pogłębionym studiami i podróżami zagranicznymi, jak i szeregowi absolwenci seminariów duchownych. Są bywalcy „obiadów czwartkowych" czyli intelektualno-artystycznych spotkań odbywanych dla wybrańców na Zamku Królewskim. Są uhonorowani orderem św. Stanisława, odznaczeniem, które nowy król ustanowił w 1765 r. dla tych wszystkich, którzy poniosą szczególne zasługi dla kraju, medalem „Merentibus”, a nawet medalami bitymi specjalnie na cześć jednej osoby, są tacy, których chwalono w wierszach za patriotyczną postawę, ale i tacy, których poeci ganili za nadmierne wtrącanie się do spraw publicznych ${ }^{34}$. Według przyjętych w nauce polskiej kryteriów generacyjnych dotyczących epoki Oświecenia wśród kaznodziejów okolicznościowych przeważali urodzeni w latach 30. i 40. XVIII w. Było to tzw. pokolenie twórców ${ }^{35}-$ najbardziej samodzielne i aktywne na polu literatury i polityki, które uczestnicząc w życiu publicznym było zarówno nadawcą, jak i odbiorcą w procesie społecznej i literackiej komunikacji.

Obserwacja polityczno-społecznego kaznodziejstwa epoki stanisławowskiej pozwala wyodrębnić ośrodki, gdzie głoszono i publikowano tego typu wystąpienia. Czołową rolę odgrywała Warszawa. Tu rezydował monarcha ze swoim dworem, magnaci posiadali pałace, a najaktywniejsi biskupi spędzali większość czasu przy

\footnotetext{
${ }^{34}$ Znajomość środowiska duchownych, głoszących kazania okolicznościowe w czasach stanisławowskich, na podstawie własnych poszukiwań i ustaleń. Ze względu na szczupłość miejsca podaję informacje podsumowujące. Wiersz pochwalny skierowany został do Michała Karpowicza, skarcono zaś Ignacego Witoszyńskiego [M. Wolski], Do... księdza Michała Karpowicza z okazji kazania jego O miłości Ojczyzny [B.m.r.]; S. Trembecki Kazanie do kaznodziejów z powodu kazania adwentowego ks. Witoszyńskiego w kaplicy królewskiej 1788 mianego, w: idem, Poezje, t. 2, Warszawa 1820, s. 159-162.

${ }^{35}$ E. Aleksandrowska, Geografia środowiska pisarskiego, w: Problemy literatury polskiej okresu oświecenia. Praca zbiorowa pod red. Z. Golińskiego, ser. 2, Wrocław 1977, s. 219.
} 
królu, w diecezjach pozostawiając zastępców. Tu odbywały się obrady parlamentu, funkcjonowały najsłynniejsze $w$ kraju instytucje życia publicznego $i$ kulturalnego - szkoły, biblioteki, drukarnie, teatry. W Wielkim Księstwie Litewskim podobną rolę pełniło Wilno, w którym wielki miłośnik fizjokratów biskup Józef Ignacy Massalski rozwinął szeroką działalność literacką i naukowa. Litewskie Grodno, małopolski Lublin i wielkopolski Piotrków Trybunalski znane były ze względu na odbywające się tam kadencje trybunałów. Wygłaszane w tych miastach kazania najczęściej drukowano w Warszawie i Wilnie, w oficynach królewskich lub zakonnych. Nie bez znaczenia był czas i miejsce wygłoszonej oracji. W przeciwieństwie do popularnych homilii, które odpowiadały tylko miejscu w kalendarzu liturgicznym, kazanie okolicznościowe przyporządkowane jest ściśle danemu wydarzeniu i nie może być w dowolny sposób powielane, choć zdarzały się wypadki zapożyczeń pewnych myśli sformułowanych przez autora. Istotne jest także miejsce jego wygłoszenia. Nie były to przeciętne kościoły parafialne, lecz świątynie wybrane. W Warszawie miejscem takich wystąpień duchowieństwa stała się sąsiadująca z Zamkiem Królewskim kolegiata św. Jana, misjonarski kościół św. Krzyża na Krakowskim Przedmieściu, który szczególnie upodobał sobie monarcha, a obok którego funkcjonowało jedno z najsłynniejszych seminariów misjonarskich w kraju, wreszcie pijarska świątynia na Długiej, skąd od czasów reform Stanisława Konarskiego na cały kraj promieniowały idee oświeconego katolicyzmy oraz parafialny kościół pod wezwaniem Najświętszej Maryi Panny na Nowym Mieście. Wszystkie te miejsca znajdowały się przy najbardziej uczęszczanym trakcie komunikacyjnym stolicy, gdzie skupiało się życie towarzyskie i polityczne ${ }^{36}$. W mniejszych miastach były to przede wszystkim kolegiaty, czyli kościoły główne, w Wilnie akademicka świątynia pod wezwaniem św. Jana ${ }^{37}$.

Odbiorcą tego typu kazań były te grupy społeczne, które brały najbardziej aktywny udział w życiu publicznym państwa. Świadczą o tym miejsce, czas i tematyka kościelnych wystąpień. Problemy, o jakich mówili kaznodzieje, były bliskie ludziom aktywnym politycznie, nawet jeżeli ich poglądy odbiegały od linii kazania. Były to także zagadnienia, które od czasów reform edukacyjnych poruszano w nauczaniu szkolnym. Tak więc oralna sytuacja komunikowania ze strony kaznodziei oraz „audiowizualny” odbiór ze strony uczestników sejmu, sejmiku trybunału funkcjonował jako wykładnik spraw publicznych. Wygłoszone kazanie przybierało formę druku w kilku określonych sytuacjach. Gdy zyskało aprobatę władz kościelnych, jego wartość docenił monarcha lub słuchająca je publiczność zdecydowanie żądała jego edycji. Zaistnieć mogła jedna lub wszystkie okoliczności sprzyjające opublikowaniu takiej mowy. Prasa informując o najważniejszych uroczystościach państwowych wspominała także o towarzyszącym ich kazaniom i reakcjach audytorium, prezentowała osobę mówcy $i$ temat jego oracji. W przeciwieństwie do wieloletnich i wielotomowych wydań homilii - kazania okolicznościowe publikowano

${ }^{36} \mathrm{O}$ traktach komunikacji literackiej - K. Dmitruk, Literatura - społeczeństwo - przestrzeń. Przemiany układu kultury literackiej, Wrocław 1980, s. 251-252.

${ }^{37}$ Zestawienie dokonane na podstawie informacji dotyczących miejsc wygłoszenia około dwustu znanych mi kazań okolicznościowych. 
niemal na bieżąco. Druk przeciętnie trwał około trzech tygodni. Mowa duchowna przybierała formę kilkudziesięciostronicowego samodzielnego tekstu. Jego cena wynosiła najczęściej 1 złp. Edycję poprzedzała wyraźna reklama prasowa. $\mathrm{Na}$ podstawie anonsów księgarskich wnioskować możemy, że kazania okolicznościowe zdobywały szybkiego nabywcę, w przeciwieństwie do zalegających składy księgarskie kazań popularnych. O ich atrakcyjności decydowała aktualność tematyki, cena, łatwość przyswojenia niewielkiego tekstu. Jednym z elementów zachęcających do kupna i wskazujących na odbiorców tego typu piśmiennictwa było umieszczanie przed tekstem właściwym spisu posłów i senatorów na kolejne sejmy, bądź listy deputatów, czyli uczestników trybunałów, a także specjalne zwroty pochwalne do marszałków, prezydentów i obradującej szlachty, które formułował kaznodzieja. W zgodzie z panegiryczną konwencją autor kazania nawiązywał niekiedy do historycznych i obywatelskich dziejów zasłużonych dla ojczyzny rodzin. Zdarzało się, że duchowny orator zamieszczał opinie o swoim utworze, jakie formułowali inni. Mistrzem w autoreklamie był najwybitniejszy kaznodzieja epoki, Michał Karpowicz. Wielbicielem jego oratorskiego talentu okazał się sam Stanisław August. który prowadził z Karpowiczem korespondencję, a nawet ingerował w tekst jednego z kazań. Mówca postanowił to wykorzystać, wszystkie królewskie uwagi i opinie, jakie wyraził o jego zdolnościach monarcha, umieścił w specjalnie dodrukowanych egzemplarzach ${ }^{38}$. Środowiskami opiniotwórczymi, a także inspirującymi dla kaznodziejów, podobnie jak w przypadku oratorstwa popularnego, była hierarchia kościelna. Świadczyła o tym niejednokrotnie forma cenzorskiej aprobaty. Wykraczała ona poza tradycyjne biskupie imprimatur. W sposób opisowy podkreślała najważniejsze walory kazania - jego styl, poprawność językową, prawowierność wykładu religijnego i wartości obywatelskie ${ }^{39}$. Najwybitniejsi rząd-

\footnotetext{
${ }^{38}$ Prasa informacyjna - „Gazeta Warszawska” i „Gazety Wileńskie” - przynosi liczne informacje o żądaniu druku kazań przez „publiczność". Wymiana listów między Stanisławem Augustem a Michałem Karpowiczem dotyczyła między innymi słynnego wileńskiego kazania $O$ zgodzie $i$ jedności obywatelów, wygłoszonego przed Trybunałem Wielkiego Księstwa Litewskiego w 1786 r. w związku z tzw. aferą Dogrumowej. Karpowicz korespondujący z królem już od kilku lat i tym razem przesłał monarsze wspomnianą orację. Król wniósł do tekstu swoje poprawki, nieco tagodząc ton wypowiedzi, oraz wydał przywilej na zbiorową edycję kazań, z którego Karpowicz nie skorzystał. W świetle korespondencji wydaje się, że kazanie $O$ zgodzie $i$ jedności obywatelów zostało wydrukowane „na żądanie publiczności" przed uwzględnieniem królewskich poprawek, dopiero potem Karpowicz zarówno królewską opinię o sobie, jak i uwagi króla do treści kazania umieścił w osobnym Przydatku do rozesłanego kazania mianego a, 1786. Uwage o istnieniu takiego druku zniszczonego w 1944 podaje Nowy Korbut (t. 5, s. 92). Korespondencja M. Karpowicza ze Stanisławem Augustem - Bibl. Czart. rps 697 ( $m f$ BN 20576). Warto dodać, że wyrażona w tym liście opinia monarchy o najwybitniejszym kaznodziei epoki, ,iż w takim gatunku jeszcze Polska nie miała kaznodziei, który by naukę o prywatnych i osobistych każdego człowieka powinnościach umiał tak jasno i tak użytecznie połączyć z powinnościami obywatelskimi" przeszła w identycznej nieomalże formie do XIX-wiecznych podręczników wymowy kościelnej, bez żadnej informacji, iż sformułował ją ostatni król Rzeczypospolitej.

${ }^{39} \mathrm{Już}$ pierwsze wystapienie trybunalskie M. Karpowicza 13 czerwca 1775 roku w Wilnie zyskało uznanie w oczach cenzury kościelnej. W swej aprobacie urzędnik kościoła napisał: „szczęśliwe tu i gruntowne krasomówstwo, uczy razem prawdziwej religii i obywatelstwa. Dałby Bóg! żeby krajowe ambony brzmiały podobną nauką i wymową dla wiecznego i doczesnego uszczęśliwienia ludu chrześcijańskiego". (M. Karpowicz, Kazania i inne dzieła, Warszawa 1814, t. 7: Kazania trybunalskie, s. 2. Przykłady podobne można mnożyć).
} 
cy diecezji potrafili narzucać podległemu sobie duchowieństwu treści kazań. Tak było z biskupem wileńskim Józefem Ignacym Massalskim, który podczas kościelnego jubileuszu $1776 \mathrm{r}$. nakazał podwładnym opracowanie i wygłoszenie kazań w duchu modnego w Polsce fizjokratyzmu ${ }^{40}$. Wspominany już wielokrotnie Michał Karpowicz wygłosit, a następnie opublikował cykl oracji kościelnych, w których prezentował myśl fizjokratyczną powołując się między innymi na Table raisonnée des principes de l'économie politique Pierre'a Samuela Du Pont. Wygłoszone wtedy oracje ukazały się w $1777 \mathrm{r}$. jako drugi tom kazań pod wymownym tytułem Religii i społeczności ${ }^{41}$. Autor zadedykował je biskupowi Massalskiemu, który był inicjatorem tematów wystąpień. I tym razem cenzura kościelna wysoko oceniła duchowne mowy Karpowicza, zarówno pod względem tematyki niezbędnej dla oświecenia społeczeństwa, jak i formy wypowiedzi oraz prawowierności religijnej. Należy jednak podkreślić, że notę cenzorską firmował swym nazwiskiem Tomasz Husarzewski - regens seminarium misjonarskiego w Wilnie, jeden z najbliższych współpracowników biskupa Massalskiego, autor wspomnianej już Książki jubileuszowej. Świadczy to o dobrze i świadomie zaplanowanej, a także konsekwentnie przeprowadzonej akcji w środowisku rządcy diecezji wileńskiej, który nieprzypadkowo przecież wykorzystał wielkie kościelne święto do głoszenia postępowych haseł fizjokratyzmu. Równocześnie widać jak bardzo elitarny, zamknięty był krąg inicjatorów oraz wykonawców działalności i twórczości kaznodziejskiej nastawionej na cele pozaewangeliczne. Także odbiorcą tego typu twórczości było wąskie grono politycznej i intelektualnej elity kraju, otwartej na nowe prądy. Równocześnie takie właśnie kazania budziły największe oburzenie i sprzeciw środowisk tradycyjnych, obawiających się zmian w systemie społecznej relacji, a także przedstawicieli ortodoksyjnego nurtu w Kościele katolickim, którzy przeciwni byli oświeceniowej idei kościoła użytecznego i przeobrażającego się wewnętrznie. Sytuacja taka miała miejsce podczas wspomnianego już jubileuszu w Wilnie w 1776 r. Kazania Michała Karpowicza budziły uznanie wśród zwolenników reform. Prasa podkreślała ich znaczenie dla „oświecenia” społeczeństwa. Twierdzono, że zawarte w kazaniach „gruntowne uwagi, powszechne w umysłach oświeconych sprawiły ukontentowanie"42. W jednej ze swoich mów Karpowicz wystąpił z propozycją stanowej nauki dla chłopów, powołując się na fizjokratyczne hasła o nadrzędności kmiecego stanu. Kaznodzieja wyraźnie skrytykował zachowawczą społecznie postawę ubogiej szlachty, która ze względów ekonomicznych bała się wszystkich zmian w sto-

${ }^{40} \mathrm{O}$ osobistych powiązaniach biskupa wileńskiego I. J. Massalskiego z fizjokratami francuskimi traktuje m.in. praca A. Joberta Magnats polonais et physiocrates français (1767-1774), Paris 1941. Ułożenie materii kazań powierzył biskup swojemu zaufanemu współpracownikowi i znanemu kaznodziei, misjonarzowi Wilhelmowi Kalińskiemu, zaś książkę jubileuszową przygotował inny znany misjonarz, Tomasz Husarzewski. (A. Korniłowicz, O życiui pismach ks. Wilhelma Kalińskiego, misjonarza, Wilno 1829, s. 9. A. Szletz, Współpraca misjonarzy z Komisją Edukacji Narodowej (1773-1794). Przyczynek do historii kultury i oświaty w Polsce, Kraków 1946, s. 114. [T. Husarzewski], op. cit, s. $38,97$.

${ }^{41}$ M. Karpowicz, Kazania. Religii i społeczności, t. 1-2, Warszawa - Wilno, 1776-1777.

42 "Gazety Wileńskie" nr 39 z 21 X 1776. 
sunkach między wsią a dworem. Apelował natomiast do arystokracji i samodzielnej gospodarczo oraz najbardziej świadomej politycznie szlachty średniej, w których to grupach upatrywał trzon obozu reformatorskiego. Wypowiedział się także przeciwko zabobonom, fanatyzmowi religijnemu, wierze $w$ domniemane cuda $i$ czary. Propagował religię i Kościół oświecony, czyli oczyszczony z nadmiaru barokowej obrzędowości, otwarty i użyteczny społecznie. Taka postawa kaznodziei spotkała się z gwaltowną reakcją ze strony dwóch grup słuchaczy - przedstawicieli obawiającej się reform szlachty prowincjonalnej i kleru zakonnego. Po zakończeniu kazania miał miejsce w kościele nieprzyjemny incydent. $\mathrm{Na}$ ambonę wdarł się dominikanin i z gorliwością zaczął odwoływać słowa Karpowicza jako „naukę libertyńską, wolterowską i bezbożną". Siłą ściągnięto go z mównicy. Sprawa skończyła się w konsystorzu, który potępił zachowanie oburzonego kapłana jako niezgodne z zaleceniami i wolą zwierzchności kościelnej, w tym inicjatora tematów kazań biskupa Massalskiego. W wyroku podkreślano, że chociaż przeciwko Karpowiczowi sformułowano wiele potwarzy, to kontrowersyjne kazanie zawiera nauki pożyteczne dla Kościoła i społeczeństwa. Natomiast postawę zakonnika potępiono jako „nieoświeconą". Winowajcę obłożono suspensą. Karpowicz otrzymał wyraźne poparcie biskupa i oświeconej części opinii publicznej. Wykorzystał ten incydent dla wzmocnienia swojej popularności. Wzbudzająca tyle emocji oracja została natychmiast opublikowana, z dokładnym opisem całego wydarzenia ${ }^{43}$. Spektakularnie wyrażony sprzeciw grupy publiczności oralnej nie zaszkodził reklamie prasowej kazania, a po szybkości jego sprzedaży wnioskować możemy, że publiczność czytelnicza nie zawiodła oczekiwań autora i jego protektora biskupa Massalskiego.

W przedstawionym tu tekście starałam się podkreślić specyfikę literatury kaznodziejskiej wobec innego typu piśmiennictwa. Kościół był tą instytucją życia publicznego, która poprzez kontakt audiowizualny docierała do najliczniejszego odbiorcy. Słuchacze kazań czyli uczestnicy nabożeństw wywodzili się ze wszystkich środowisk społecznych. Wydaje się jednak, że w niewielkim stopniu tworzyli oni grupy współodpowiedzialne za przebieg kontaktu werbalnego. W przeważającej mierze byli biernymi odbiorcami przekazywanego im komunikatu. Wpływ słuchaczy na treści i kształt kazań był znikomy, groziło to bowiem podważaniem autorytetu Kościoła. Jednostkowe próby ingerencji wynikały z niezrozumienia i lęku, świadczyły raczej o zerwaniu łańcucha komunikacyjnego, a nie świadomej krytyce. Druk kazania zawężał i częstokroć zmieniał odbiorcę. Publiczność czytelnicza to głównie środowiska XVIII-wiecznej „klasy politycznej” i „warstwy oświecone”. Tutaj formuła komunikatu literackiego wynikała ze wspólnoty wykształcenia, ideałów, poczucia etycznej odpowiedzialności za państwo. Stopień integracji był wysoki. Otoczenie światłych biskupów, dwór królewski, salony literackie, środowiska

${ }^{43}$ M. Karpowicz, Kazanie IV jubileuszowe, w porządku 80... dnia 24 września w kościele św. Ducha miane „O powinnej poddanym od panów miłości względem ich duszy, a zatem o powinności wyprowadzenia ich z tej grubości rozumu, w której zostają i o szkołach parafialnych", w: idem, Kazania $i$ inne dzieła, Warszawa 1813, t. 6, s. 85-87. 
akademickie - szczególnie wileńskie - instytucje władzy i społecznego ładu sejm, sejmik, trybunał, wreszcie prasa tworzyły środowiska opiniotwórcze. Czy kazania, szczególnie te polityczno-społeczne, wywierały rzeczywisty wpływ na publiczną sferę życia? Niektórzy badacze wyolbrzymiają ich znaczenie. Twierdzą, że oświecona ambona była „tubą" propagandową Stanisława Augusta, który wykorzystywat ją do propagowania haseł nowoczesnego monarchizmu. Istotnie król wykorzystywał wszystkie środki społecznego przekazu, ale także w porozumieniu z kaznodziejami "reżyserował" ich wystappienia. Czy osiągat jednak zamierzony skutek? Jest to temat do dyskusji. Niewątpliwie rola kazań jako twórczości nastawionej na propagowanie idei odrodzenia państwa polskiego, a następnie jego obrony wzrosła w czasach Sejmu Wielkiego, Konstytucji 3 Maja i insurekcji kościuszkowskiej. Sądzę jednak, że nie należy przeceniać wpływu twórczości kaznodziejskiej na obywatelskie zachowanie odbiorców i ich postawy społeczne (pomijam tu skomplikowane kwestie świadomości religijnej). O instrumentalnym, czy nawet koniunkturainym traktowaniu tego typu komunikatu, a więc także jego publiczności, świadczyć może fakt, że gdy po roku 1795 zabrakło i króla, i polskiej instytucji państwa, najsłynniejsi duchowni oratorzy epoki stanisławowskiej bez szczególnych oporów przeszli „na służbę" u obcych władców. Najwybitniejszy duchowny orator epoki, Michał Franciszek Karpowicz - „Skarga XVIII wieku”, wygłosił w 1796 r. kazanie homagialne podczas przysięgi na wierność, składanej królowi pruskiemu. Zaś były kaznodzieja królewski, znany ze swych wystąpień insurekcyjnych, Ignacy Witoszyński, w serwilistycznym wręcz kazaniu z 1795 r. głosif chwałę Katarzyny $11^{14}$. A może wręcz przeciwnie, taka właśnie lojalistyczna postawa duchownych wynikała $z$ ich wiedzy o nastrojach społecznych. Wszak tendencje uległości i pogodzenia się z losem panowały wśród znakomitej części warstwy szlacheckiej i magnackiej. Może w ten sposób kaznodzieje artykułowali powszechny lęk i nadzieje, jakie nurtowały Polaków po upadku państwa. Byłoby to dowodem wspólnoty uczuć i myśli, jaką dzieli twórca ze swoim audytorium.

${ }^{44}$ M. Karpowicz, Mowa przed zaprzysiężeniem homagii od prowincji dotąd polskich, Litwy, Żmudzi, Mazowsza i Podlasia w pewnych częściach... Fryderykowi Wilhelmowi królowi pruskiemu, w Gembinie dnia 6 go lipca roku 1796..., Warszawa (1796); I. Witoszyński, Kazanie na uroczystym obchodzie imienin Najjaśniejszej i Naipotężniejszej Monarchini Katarzyny Wtórej Imperatorowej całej Rosji... w Kamieńcu Podolskim w kościele katedralnym obrządku łacińskiego dnia 5 grudnia nowego kalendarza R.P. 1795 mówione, Poczajów 1796. 